\title{
The Impact of Nonfarm Activities on Rural Farm Household Income and Food Security in the Upper East and Upper West Regions of Ghana
}

\author{
Daniel Osarfo, Bernardin Senadza, Edward Nketiah-Amponsah \\ Department of Economics, University of Ghana, Legon, Ghana \\ Email: danosaf291@yahoo.com, bsenadza@ug.edu.gh, enamponsah@ug.edu.gh
}

Received 16 April 2016; accepted 31 May 2016; published 3 June 2016

Copyright (C) 2016 by authors and Scientific Research Publishing Inc. This work is licensed under the Creative Commons Attribution International License (CC BY). http://creativecommons.org/licenses/by/4.0/

(c) (i) Open Access

\begin{abstract}
Research shows that participation in rural non-farm activities exerts a pronounced impact on agriculture, household farm decisions, rural development, income and welfare as well as household food security. This paper investigates the impact of participation in non-farm activities on household income and food security among farm households in the Upper East and Upper West Regions of Ghana. Using the Recommended Daily Calorie Required (RDCR) approach, the study finds that 45 percent of households in the two regions are food insecure. Propensity score matching (PSM) results indicate that participation in non-farm work has significant positive effect on household income and food security status. The policy implications of the findings are discussed.
\end{abstract}

\section{Keywords}

Non-Farm Activities, Food Security, Household Income, Rural Farm Households, Propensity Score Matching, Upper East Region, Upper West Region, Ghana

\section{Introduction}

The problem of food insecurity is rife in many developing countries of the world. Although emerging economies are experiencing rapid economic growth, resulting in increased food security scores, the gap between developed and developing countries is still wide. The situation is more acute for Sub-Saharan Africa (SSA), with the region taking bottom spot in the 2015 Global Food Security Index (GFSI) rankings [1]. Although agriculture-powered growth have played a key role in tackling food insecurity and improving the economies of many Latin American 
and Asian countries, the same cannot be said to have happened in Africa [2]. According to [3], addressing food insecurity in Africa through increased food production alone may be inadequate. Undoubtedly, agricultural development is essential for reducing hunger and poverty in rural areas, but non-agricultural growth is important as well [4]. This brings into sharp focus on the role of non-farm activities. Non-farm income activities refer to all those activities associated with waged work or self-employment in income generating activities (including income in-kind) that are not agricultural but which generate income (including remittances etc.) in rural areas [2]. It typically involves activities such as construction, business (trade), rural tourism, processing (manufacturing) and/or marketing of agricultural products, repair services, transportation services, and extraction activities amongst others [2]. Research over the past two or three decades shows that diversification is the norm [5] rather than the exception. Resultantly, smallholder rural farm households hold a portfolio of income sources, and non-farm income is a major component of that portfolio. ${ }^{1}$ From a policy standpoint, therefore, efforts must be geared toward enhancing rural households' access to additional sources of income through non-farm employment.

Literature buttresses the fact that participation in rural non-farm activities exerts a pronounced impact on rural agriculture [6] [7] household farm decisions [6] [8], rural development [9], income and welfare [10] and household food security [11] [12]. According to [9], the absorption of more labor in non-farm sectors in east and south-east Asia has increased agricultural productivity and helped pull millions out of poverty [11]. [12] and [9] report that engaging in non-farm work improves household food security.

Farming is the main economic activity in northern ${ }^{2}$ Ghana, where poverty rates are much higher than the rest of the country. While Ghana ranks ${ }^{3}$ favorably among Sub-Saharan African countries in terms of the food security situation, it cannot be said to be out of the woods yet, given the level of poverty in the northern parts of the country. [11] observes that in the Northern Region of Ghana, the poverty situation is worse for households who depend solely on proceeds from farming as income. While output from the farm is the principal source of food and income, very often some households may not have enough food to consume in the lean season let alone generate any surpluses to cater for other household needs such as education, health, clothing, and shelter as well as fulfilling obligations to social and professional associations they may belong to. The northern sector of Ghana where agriculture is the major economic activity is also noted for a long dry season. This period is associated with difficulty in accessing food and water. In a participatory poverty assessment conducted by [13] in Beo Tankou, a village in the Bongo District of the Upper East region, a group of men prepared a food availability calendar which showed that food is in short supply from the months of March to June in each year. Clearly, food insecurity is a major challenge, especially for rural farm households, in northern Ghana. In response to food shortages, households often resort to various coping strategies including migrating to the southern parts of the country, selling livestock and household assets, reducing food intake or settling for less preferred food [14]-[16]. Diversifying into non-farm economic activities is another way to minimize the food insecurity risk that households in northern Ghana face. Several studies (see [17]-[21]) have shown that rural farm households that combine their farming activities with non-farm income activities are better able to smooth income and consumption. In other words, having a diversified portfolio of income generating activities (and hence a diversified set of income sources) is a sure way to minimize income variability and to ensure a minimum level of income [18].

The relevant questions this paper seeks to address are: 1) What are the food security status of farm households in northern Ghana? 2) What factors influence farmers' involvement in non-farm activities in northern Ghana? 3) What impact do non-farm activities have on farm household income and food security status in northern Ghana? The main objective of the paper is to assess the impact of non-farm activities on household income and food security status of rural farm households in the Upper East and Upper West Regions of Ghana. Specifically, the paper seeks: 1) to determine the food security status of farm households in the two regions; 2) to identify factors that influence farm households' involvement in non-farm activities in two the regions; and 3) to estimate the impact of non-farm activities on household income and food security status of rural farm households in the two regions.

The choice of these two regions is informed by the fact that they rank among the three poorest regions of

\footnotetext{
${ }^{1}[2]$ reports that non-farm income on average constitutes about 42 percent of rural household income in Africa, 32 percent in Asia, 40 percent in Latin America, and 44 percent in Eastern Europe.

${ }^{2}$ Geographically, this comprises the three northern-most regions of Ghana, namely, Northern, Upper East and Upper West.

${ }^{3}$ Ghana ranked third, behind South Africa and Botswana, among 28 SSA countries captured in the 2015 GFSI.
} 
Ghana. ${ }^{4}$ Moreover, these regions are often plagued by conflicts resulting in the loss of assets and increased vulnerability. In addition, these regions suffer adverse weather conditions and frequent fluctuations in crop prices as well as reduction in levels of food stock due to seasonality [22]. Thus, in terms of food insecurity, these regions are ranked very high in Ghana.

Earlier work to analyze the impact of non-farm activities on household food security status in Ghana have been done by [23] and [11] for the Brong Ahafo and Northern regions of Ghana, respectively. Both these two studies find that non-farm work positively impacts on household income and food security status in selected regions in Ghana. [23] evaluated how participating in both wage- and self-employment non-farm work impacts on farm household income in Brong-Ahafo Region of Ghana. The results from the study showed that non-farm employment has a significantly positive effect on farm household income and as well significantly reduces the likelihood of being poor. Similarly, [11] examined the impact of non-farm work on household income and food security among farm households in the Northern Region of Ghana and finds that participation in non-farm work exerts a positive and statistically significant effect on household income and food security status. [24], using the fifth round of the Ghana Living Standards Survey (GLSS 5) ${ }^{5}$ data also found that participation in non-farm activity had a positive impact on the welfare (measured as per capita consumption per adult equivalent) of rural households in Ghana. Clearly, the positive effects of non-farm activity participation for especially rural households are numerous.

While the work of [11] focused on only one of the three northern regions of Ghana - the Northern Region the indicators that measured food security in their study bothered only on access to food and availability of food, neglecting the other essential facets such as quality and safety of food, which are important dimensions, but are often not considered. This paper not only focuses on the other two northern regions of Ghana, namely, Upper East and Upper West, but it also constructs an index to measure household food security while considering all the essential facets such as quality and safety of food. Furthermore, we employ a more recent survey which potentially captures current food security challenges in the two regions studied.

The rest of the paper is structured as follows. The next section discusses the methods and the data collection process. Section three presents and discusses the findings, while section four concludes with policy recommendations.

\section{Methods and Data}

\subsection{Study Area and Data}

To ensure reliability and a statistically representative sample, the survey took place in three districts in each of the two regions, namely, Bolgatanga Municipal, Bawku West and Kasena Nankana East districts in the Upper-East Region, and Wa Municipal, Nandom and Lambussie Karni districts in the Upper-West Region, which are all predominantly farming districts. Using [25] sample size determination, a representative sample of 400 was chosen for this study. A list of communities within the selected districts in the two regions per the 2010 Population and Housing Census was obtained from [26]. From this list, eight communities were randomly selected from each of the two municipal districts while six communities were selected from each of the other 4 districts. Ten households were surveyed in each of the selected communities, thus totaling eighty household interviews in each of the two municipal districts and sixty interviews in each of the four other districts. The choice of eighty households from selected communities in each municipal district and sixty households from selected communities in each of the four other districts, was informed by key informant interviews which pointed out the likelihood of the more urbanized or municipal districts to have a higher concentration of non-farm participants and the likelihood of the other districts to have a higher concentration of full time farm households. Thus, it enabled us to interview a sizeable proportion of farm households that also engage in non-farm work. Moreover, it is worth noting that although Bolgatanga and Wa are municipal districts, there are some communities that are rural in nature. Data collection was begun in the second week of January, 2014 and lasted for four weeks. The data was entered and analyzed using STATA 13.

\footnotetext{
${ }^{4}$ According to national poverty statistics, Upper West is the poorest region in Ghana with poverty incidence of 71 percent. Northern region is second poorest with poverty incidence of 50 percent, while Upper East is the third poorest region with poverty incidence of 44 percent. The national incidence is 24 percent [27].

${ }^{5}$ The GLSS is a nationally representative household survey conducted along the lines of the World Bank's Living Standards Measurement Surveys (LSMS).
} 


\subsection{Construction of Food Security Index}

In order to assess the impact of non-farm activities on household food security, we constructed a food security index. A Food Security Index $(Z)$ is constructed to determine the food security status of each household based on a food security demarcation using the Recommended Daily Calorie Required (RDCR) approach employed by [28] and [29]. The Food Security Index is given by:

$$
Z_{i}=\frac{A_{i}}{R_{i}}
$$

where $Z_{i}$ denotes Food Security Index for the $i^{\text {th }}$ household; $A_{i}$ is Actual Daily Calorie Intake of $i^{\text {th }}$ household and $R_{i}$ is the Recommended Daily Calorie Required (RDCR) of the $i^{\text {th }}$ household. The study employed [30] and [31] standard of 2,900 kcal as the standard for daily recommended calorie level which is required to be consumed by each household. Evidently, different age groups have different calorie requirements. Thus, all households were categorized into three different age groups, namely, at most five years old, between six and 18 years, and above 18 years. The daily energy calorie requirements of each of the three age groups of the household were converted to the adult equivalent using the conversions shown in Table 1.

The adult equivalent of the total energy requirement for children is obtained by multiplying the total number of children below age six in each household by a conversion factor of 0.4 and RDCR of $2900 \mathrm{kcal}$. The adult equivalent of the total food requirement for children between six and 18 years is obtained by multiplying the total number of household members within this age bracket by a conversion factor of 0.7 and RDCR of $2900 \mathrm{kcal}$. In the case of persons aged over 18 years, the total number in each household is multiplied by the recommended calorie requirement of $2900 \mathrm{kcal}$. The total Daily Calorie Requirement (DCR) for each household was obtained by summing the requirements for the three age groups.

Households' daily food consumption or Daily Calorie Intake (DCI) was obtained from households' own food production and purchases to supplement farm production. The data on actual food quantity of maize, millet, rice, beans groundnut, and yam consumed by each household per week or month was converted into kilogram. The energy content of $1 \mathrm{~kg}$ of each foodstuff (maize, millet, rice, beans, groundnut, and yam) is presented in Table 2.

The total quantity (in kilogram) of each food consumed was then multiplied by the energy content (e.g. total kilogram of maize consumed per week $* 3950 \mathrm{kcal}=$ total kcal of maize consumed). This was done for all the other foodstuff. The total kilocalories of maize, millet, rice, beans groundnut, and yam consumed by each household were added, converted to yearly averages and divided by 365 to obtain Actual Daily Calorie Intake. Households whose DCI was greater than or equal to their RDCR were deemed food secure households while households whose DCI was less than their RDCR were considered food insecure households.

Table 1. Recommended daily energy intake and equivalent scale.

\begin{tabular}{ccc}
\hline Age Category (Years) & Average Daily Energy Required & Equivalent Scale \\
\hline Children $(<6$ years $)$ & 1150 & 0.4 \\
Children $(6-18$ years $)$ & 2250 & 0.7 \\
Adults $(>18$ years $)$ & 2900 & 1.0 \\
\hline
\end{tabular}

Source: [30].

Table 2. Food and energy content (Calorie/kg).

\begin{tabular}{ccc}
\hline Food Crop & Calorie/Kilogram \\
\hline Maize & 3590 & 3410 \\
Millet & Rice & 3640 \\
Beans & 3380 & 3320 \\
Groundnut & Yam & 297.5 \\
\hline
\end{tabular}

Source: [32]. 


\subsection{Modeling Non-Farm Activity Participation}

A farm household's decision to either participate in non-farm work or not is assumed to be the outcome of a vector of factors related to the farmers' resources and constraints. As noted by [33], a positive number of non-farm hours will be observed for an individual if the potential market wage is greater than the reservation wage. However, these differential wages are not observable. What is observed is the decision to participate, or not to participate in non-farm work. This study postulates that a farm household will only engage in non-farm work when it gains extra income to complement its farm income (reservation wage). The study begins by observing participating and non-participating households, as to whether they differ significantly in terms of household characteristics, farm characteristics and assets. Thus, Logistic regression model is employed to estimate the determinants of non-farm work participation and to generate estimates for propensity scores.

Based on theoretical and empirical considerations (see [34]-[37]), we specify the following model for nonfarm employment participation:

$$
\begin{aligned}
& N \text { farm }=\beta_{0}+\beta_{1} \text { sex }+\beta_{2} \text { age }+\beta_{3} \text { ages } q+\beta_{4} \text { reg }_{j}+\beta_{5} \text { educ } k+\beta_{6} \text { married }_{m} \\
& +\beta_{8} \text { hsize }+\beta_{9} v g m_{l}+\beta_{10} \text { accloan }_{o}+\beta_{11} \text { rnet }+\beta_{12} \text { hsefac } \\
& +\beta_{13} \text { numfarms }+\beta_{14} \text { farmmkt } \beta_{15} \text { assets }_{q}+\varepsilon
\end{aligned}
$$

The dependent variable is non-farm work participation ( $N$ farm) and takes the value 1 if at least one member of the household participates in non-farm work, and zero otherwise. Participation in non-farm activity by a household is specified as a function of household demographic, socio-economic and community variables. The definition and measurement of the explanatory variables are presented in Table 3.

\subsection{Propensity Score Matching}

The outcome variables are food security (FSS) as measured by the RDCR index and household income (HHINC) measured in local currency units (Ghana cedis, GHф). According to [38], an impact evaluation is essentially a problem of missing data, because of the inability to observe the outcomes on intervention participants had they not enrolled or without observable information on the counterfactual. [38] emphasizes that it is ethical to choose a comparison group that is very similar to the treated group, such that the treated group would have had outcomes similar to those in the untreated group.

[39] pointed out several stages in propensity score estimation. First, propensity scores are estimated, and then an appropriate matching algorithm is selected. These steps are followed by a revision of overlap and assessment of matching qualities. The predicted propensity scores can then be used to estimate treatment effects. The most common treatment effects in the evaluation literature include the Average Treatment Effect (ATE) which captures the treatment effect for the whole sample, Average Treatment Effect on the Treated (ATT) or the participation effect, and the Average Treatment Effect on the Untreated (ATU). Notably [40] indicate that the parameter of interest in the estimation of the propensity score is the Average Treatment Effect on the Treated (ATT) since it suffices in providing specific estimate of the impact of participation on non-farm work.

However, having assumed confoundedness, one acceptable approach to assessing relevant outcomes in a counterfactual framework is to examine not only the ATT but also the ATU which captures the effect of treatment on individuals who do not participate in non-farm work. Several matching algorithms can be used including the nearest neighbor matching, caliper matching, and the kernel matching. This paper employs the nearest neighbor matching technique, which matches either with or without replacement each participant with its closest neighbour with similar observed characteristics. The advantage of this technique is that it reduces biasedness given that each treatment group can be matched to the nearest comparison group as a result of a reduction in the propensity score distance.

The propensity score $p\left(Z_{i}\right)$ is defined as the conditional probability of participating in non-farm work given pre-participation characteristics:

$$
p\left(Z_{i}\right) \equiv \operatorname{Pr}\left[L_{i}=\mid Z_{i}\right]=E\left[L_{i} \mid Z_{i}\right] ; p\left(Z_{i}\right)=F\left\{h\left(Z_{i}\right)\right\}
$$

where $L_{i}=(0,1)$ is the indicator of non-farm work participation and $Z_{i}$ denotes a vector of pre-participation characteristics, and $F\{$.$\} can be a normal or logistic cumulative distribution. The propensity score can be pre-$ dicted with either the logit or probit model [41]. The predicted propensity scores can then be used to estimate treatment effects. 
Table 3. Definition and measurement of variables.

\begin{tabular}{|c|c|}
\hline Variable & Definition and Measurement \\
\hline \multicolumn{2}{|c|}{ Household Characteristics } \\
\hline SEX & Sex of HH Head $(1=$ Male; $0=$ Female $)$ \\
\hline AGE & Farmers' Age (In Years) \\
\hline AGESQ & Square of farmers' Age (Years * Years) \\
\hline REG & Region of HH Head ( 1 = Upper East; 2 = Upper West $)$ \\
\hline BASICEDU & HH Head Attained Basic Education $(1=$ Yes; $0=$ No $)$ \\
\hline SECEDU & HH Head Attained Secondary Education $(1=$ Yes; $0=$ No $)$ \\
\hline TEREDU & HH Head Attained Tertiary Education $(1=$ Yes; $0=$ No $)$ \\
\hline MARRIED & Marital Status of HH Head ( $1=$ Married; $0=$ Single $)$ \\
\hline HSIZE & Household Size (Continuous) \\
\hline NUMBER5 & Number of Children below 5 yrs (Continuous) \\
\hline VGM & Village Group Member $(1=$ Yes; $0=$ No $)$ \\
\hline ACCLOAN & Access to Credit $(1=$ Access; $0=$ No Access $)$ \\
\hline RNET & Road Condition Index $(1=$ Bad; 2 = Fairly Good; $3=$ Good $)$ \\
\hline HSEFAC & Distance from House to Nearest Health Facility (Km) \\
\hline \multicolumn{2}{|c|}{ Farm Characteristics } \\
\hline NUMFARMS & Number of Farms Owned (Continuous) \\
\hline FARMMKT & Distance from Farm to Nearest Market $\quad(\mathrm{Km})$ \\
\hline FARMMRD & Distance from Farm to Major Road $(\mathrm{Km})$ \\
\hline \multicolumn{2}{|c|}{ Livestock and Assets } \\
\hline CATTLE & $1=$ At Least a HH Member Raises Cattle; 0 otherwise \\
\hline SHEEP & 1 = At Least a HH Member Raises Sheep; 0 otherwise \\
\hline GOAT & $1=$ At Least a HH Member Raises Goat; 0 otherwise \\
\hline POULTRY & $1=$ At Least a HH Member Raises Poultry; 0 otherwise \\
\hline GNFOWL & $1=$ At Least a HH Member Raises Fowls; 0 otherwise \\
\hline BICYCLE & 1 = At Least a HH Member Has a Bicycle; 0 otherwise \\
\hline MOTORBIKE & $1=$ At Least a HH Member Has a Motor Bike; 0 otherwise \\
\hline TRUCK & 1 = At Least a HH Member Has a Truck; 0 otherwise \\
\hline $\mathrm{TV}$ & $1=$ At Least a HH Member Has a Television; 0 otherwise \\
\hline MPHONE & $1=$ At Least a HH Member Has a Mobile Phone; 0 otherwise \\
\hline
\end{tabular}

Source: Authors.

Given the propensity score $p\left(Z_{i}\right)$, the three effects are evaluated as:

$$
\begin{array}{r}
A T E=E\left[E\left\{Y_{i}^{*} \mid L_{i}=1, p\left(Z_{i}\right)\right\}-E\left\{Y_{i} \mid L_{i}=0, p\left(Z_{i}\right)\right\}\right] \\
A T T=E\left[E\left\{Y_{i}^{*} \mid L_{i}=1, p\left(Z_{i}\right)\right\}-E\left\{Y_{i} \mid L_{i}=0, p\left(Z_{i}\right)\right\} \mid L_{i}=1\right]
\end{array}
$$




$$
A T U=E\left[E\left\{Y_{i}^{*} \mid L_{i}=1, p\left(Z_{i}\right)\right\}-E\left\{Y_{i} \mid L_{i}=0, p\left(Z_{i}\right)\right\} \mid L_{i}=0\right]
$$

where $Y_{i}^{*}$ and $Y_{i}$ are the two counterfactual outcomes of participation and non-participation in non-farm employment.

\section{Results and Discussion}

\subsection{Food Security Status of Households}

Table 4 presents the food security status of sampled households with the use of recommended daily calorie intake of $2900 \mathrm{Kcal}$. The result indicates that more than half of the respondents $(55 \%)$ were food secure while the remaining $45 \%$ were food insecure. The summary statistics of food security status of farming households showed that the average food security index for food secure households was 1.49 (i.e. above the threshold of 1).

\subsection{Descriptive Statistics and Mean Tests}

Table 5 reports the descriptive statistics of the means, standard deviations and the difference in means for participants and non-participants of non-farm employment in the study areas. The means of both outcome variables were significantly different between participating and non-participating households before matching was done. Other variables such as age, basic education attainment by household head, village group membership, road network condition, number of farms owned, motorbike, truck and mobile phone possession had means which differed significantly between participant households and non-participant households.

\subsection{Impact of Non-Farm Employment on Income and Food Security}

Equation (2) is estimated by logistic regression for the determinants of participation in non-farm employment. The results from the logit estimation are shown in Table 6 . Among all the variables, the ones that significantly determine participation are region, basic education attainment, village group membership, road network, distance to the nearest health facility, number of farms owned, motorbike, truck and mobile phone possession.

The propensity scores are computed based on the logistic model and they serve as a tool to balance the observed distribution of covariates across the treated and the untreated group [11]. The distribution of propensity scores before and after matching as shown in Figure 1 indicates that estimating the p-score balances the treated and untreated groups adequately, a result which highlights the importance of the PSM approach.

The results of the treatment effects (ATE, ATT and ATU) for non-farm employment participation was computed by the near neighbor matching technique and is presented in Table 7. It can be observed that this matching technique produced consistent estimates of the treatment effects on the participation of non-farm employment.

The results from this matching technique were very robust, signifying the appropriateness of the matching algorithm employed. The ATT for household income indicates that participating in non-farm work increases household income by some Gh $\$ 5528$. The ATE is Gh $\$ 5210$, indicating the magnitude by which non-farm work participation increases household income for the total population. Similarly, the ATU of Ghф 4695 on household income shows that if non-participants of non-farm work were to participate, their household incomes would increase by about Gh $\notin 4695$. The ATT on food security from non-farm work participation is 0.42 , which is statistically significant and indicates that participating in non-farm work increases the food security index by 0.42

Table 4. Food security status of respondent households.

\begin{tabular}{ccc} 
Description & Food Secure & Food Insecure \\
\hline Percentage of Households & 54.75 & 45.25 \\
Number of Households & 219 & 181 \\
Mean Food Security Index & 1.49 & 0.59 \\
Standard Deviation & 0.37 & 0.24 \\
\hline
\end{tabular}

Source: Authors' computation using STATA 13. 
Table 5. Descriptive statistics for participation in non-farm work.

\begin{tabular}{|c|c|c|c|c|c|c|}
\hline \multirow[t]{2}{*}{ Variable Name } & \multirow[t]{2}{*}{ Variable Definition } & \multicolumn{2}{|c|}{$\begin{array}{c}\text { Participants } \\
\mathrm{N}=(247) 61.75 \%\end{array}$} & \multicolumn{2}{|c|}{$\begin{array}{l}\text { Non-participants } \\
\mathrm{N}=(153) 38.25 \%\end{array}$} & \multirow[t]{2}{*}{ Difference in mean } \\
\hline & & Mean & S.D. & Mean & S.D. & \\
\hline \multicolumn{7}{|c|}{ Treatment Variable } \\
\hline PARTICIPATE & $1=$ Yes; $0=$ No & & & & & \\
\hline \multicolumn{7}{|c|}{ Outcome Variables } \\
\hline FSS & Food Security & 1.25 & 0.49 & 0.82 & 0.55 & $0.43^{* * *}$ \\
\hline \multicolumn{7}{|c|}{ (Food secure if $>1$; Food insecure if $<1$ ) } \\
\hline HHINC & Household Income (GHC) & 8741.59 & $10,137.31$ & 2355.36 & 2447.18 & $6386.23^{* * *}$ \\
\hline \multicolumn{7}{|c|}{ Independent Variables } \\
\hline \multicolumn{7}{|c|}{ Household Characteristics } \\
\hline SEX & $1=$ Male $; 0=$ Female & 0.76 & 0.43 & 0.80 & 0.40 & -0.04 \\
\hline AGE & Farmers' Age & 49.50 & 10.79 & 52.82 & 11.80 & $-3.32^{* * *}$ \\
\hline AGESQ & Age ${ }^{*}$ Age & 2566.01 & 66.61 & 2928.02 & 99.13 & 362.01 \\
\hline REG & $0=$ Upper East; $1=$ Upper West & 1.52 & 0.50 & 1.46 & 0.50 & 0.06 \\
\hline BASICEDU & $1=\mathrm{Yes} ; 0=\mathrm{No}$ & 0.74 & 0.44 & 0.61 & 0.49 & $0.12^{* *}$ \\
\hline SECEDU & $1=$ Yes; $0=$ No & 0.33 & 0.47 & 0.25 & 0.44 & 0.07 \\
\hline TEREDU & $1=$ Yes $; 0=$ No & 0.19 & 0.39 & 0.11 & 0.32 & $0.08^{* *}$ \\
\hline MARRIED & $1=$ Married $; 0=$ Single & 0.83 & 0.37 & 0.82 & 0.38 & 0.01 \\
\hline HSIZE & Household Size & 11.04 & 9.14 & 13.42 & 12.73 & $-2.38^{* *}$ \\
\hline NUMBER5 & Children below 5 yrs & 1.58 & 1.93 & 1.82 & 2.34 & -0.24 \\
\hline VGM & Village Group Member & 0.49 & 0.50 & 0.24 & 0.44 & $0.26^{* * *}$ \\
\hline ACCLOAN & $1=$ Access $; 0=$ No Access & 0.30 & 0.44 & 0.21 & 0.41 & $0.09^{*}$ \\
\hline RNET & $\begin{aligned} \text { An index where } 1 & =\text { Bad; } \\
2 & =\text { Fairly Good; } 3=\text { Good }\end{aligned}$ & 2.17 & 0.62 & 1.96 & 0.50 & $0.21^{* * *}$ \\
\hline HSEFAC & House-Health Facility (Km) & 4.06 & 4.61 & 6.13 & 5.32 & $-2.06^{* * *}$ \\
\hline \multicolumn{7}{|c|}{ Farm Characteristics } \\
\hline NUMFARMS & Number of Farms Owned & 2.85 & 1.72 & 2.27 & 1.50 & $0.58^{* * *}$ \\
\hline FARMMKT & Farm-Market (Km) & 5.96 & 6.05 & 8.20 & 11.61 & $-2.24^{* *}$ \\
\hline FARMMRD & Farm-Major Road (Km) & 4.44 & 4.13 & 7.33 & 11.16 & $-2.89^{* * *}$ \\
\hline \multicolumn{7}{|c|}{ Livestock and Assets } \\
\hline CATTLE & $1=$ Raises Cattle; 0 otherwise & 0.63 & 0.48 & 0.60 & 0.49 & 0.03 \\
\hline SHEEP & $1=$ Raises Sheep $; 0$ otherwise & 0.65 & 0.48 & 0.70 & 0.46 & -0.05 \\
\hline GOAT & $1=$ Raises Goat; 0 otherwise & 0.88 & 0.32 & 0.91 & 0.29 & -0.03 \\
\hline POULTRY & $1=$ Raises Poultry; 0 otherwise & 0.86 & 0.35 & 0.86 & 0.35 & 0.00 \\
\hline GNFOWL & $1=$ Raises Fowls; 0 otherwise & 0.70 & 0.46 & 0.75 & 0.44 & -0.05 \\
\hline BICYCLE & $1=$ Has a Bicycle $; 0$ otherwise & 0.94 & 0.23 & 0.92 & 0.27 & 0.02 \\
\hline MOTORBIKE & $1=$ Has a Motor Bike; 0 otherwise & 0.75 & 0.43 & 0.56 & 0.50 & $0.19^{* * *}$ \\
\hline TRUCK & $1=$ Has a Truck; 0 otherwise & 0.32 & 0.47 & 0.24 & 0.43 & $0.08^{*}$ \\
\hline $\mathrm{TV}$ & $1=$ Has a Television; 0 otherwise & 0.77 & 0.42 & 0.69 & 0.46 & 0.07 \\
\hline MPHONE & $1=$ Has a Mobile Phone; 0 otherwise & 0.97 & 0.17 & 0.92 & 0.27 & $0.05^{* *}$ \\
\hline
\end{tabular}

"Significant at $10 \%,{ }^{* *}$ Significant at $5 \%$ and ${ }^{* * *}$ Significant at $1 \%$; Source: Authors' computation using STATA 13. 
Table 6. Logistic estimates for calculating propensity scores.

\begin{tabular}{|c|c|c|c|c|c|}
\hline Variable & Coefficient & Std. Error & Z-Value & Marginal Effect & $\mathrm{P}>\mathrm{Z}$ \\
\hline \multicolumn{6}{|c|}{ Household characteristics } \\
\hline SEX & -0.1939 & 0.3699 & -0.52 & -0.0428 & 0.501 \\
\hline AGE & -0.0778 & 0.0811 & -0.96 & -0.0175 & 0.338 \\
\hline AGESQ & 0.0012 & 0.0008 & 1.47 & 0.0003 & 0.143 \\
\hline REG & -0.7204 & 0.3348 & -2.15 & $-0.1606^{* *}$ & 0.029 \\
\hline BASICEDU & 0.5369 & 0.3059 & 1.76 & $0.1237^{*}$ & 0.084 \\
\hline SECEDU & -0.4902 & 0.4238 & -1.16 & -0.1129 & 0.256 \\
\hline TERTIARY & 0.4537 & 0.5037 & 0.9 & 0.0963 & 0.336 \\
\hline MARRIED & -0.2169 & 0.4023 & -0.54 & -0.0475 & 0.58 \\
\hline HSIZE & -0.0331 & 0.0203 & -1.63 & -0.0074 & 0.102 \\
\hline NUMBER5 & 0.0456 & 0.0828 & 0.55 & 0.0102 & 0.582 \\
\hline VGM & 0.9426 & 0.2874 & 3.27 & $0.2117^{* * *}$ & 0.001 \\
\hline ACCLOAN & 0.1815 & 0.3469 & 0.52 & 0.0412 & 0.595 \\
\hline RNET & 0.7813 & 0.2613 & 2.99 & $0.1755^{* * *}$ & 0.003 \\
\hline HSEFAC & -0.1018 & 0.0411 & -2.48 & $-0.0229^{* * *}$ & 0.009 \\
\hline \multicolumn{6}{|c|}{ Farm Characteristics } \\
\hline NUMFARMS & 0.2556 & 0.1013 & 2.52 & $0.0574^{* * *}$ & 0.011 \\
\hline FARMMKT & -0.0145 & 0.0167 & -0.87 & -0.0033 & 0.384 \\
\hline FARMMRD & -0.043 & 0.0403 & -1.07 & -0.0097 & 0.288 \\
\hline \multicolumn{6}{|c|}{ Livestock and Assets } \\
\hline CATTLE & -0.0597 & 0.3061 & -0.19 & -0.0134 & 0.845 \\
\hline SHEEP & -0.0392 & 0.3504 & -0.11 & -0.0088 & 0.911 \\
\hline GOAT & -0.4608 & 0.4754 & -0.97 & -0.0968 & 0.294 \\
\hline POULTRY & -0.2736 & 0.4006 & -0.68 & -0.0594 & 0.478 \\
\hline GNFOWL & -0.2387 & 0.3386 & -0.7 & -0.0526 & 0.473 \\
\hline BICYCLE & 0.3355 & 0.567 & 0.59 & 0.0784 & 0.567 \\
\hline MOTORBIKE & 1.0674 & 0.3306 & 3.23 & $0.2478^{* * *}$ & 0.001 \\
\hline TRUCK & 1.0875 & 0.3834 & 2.84 & $0.2218^{* * *}$ & 0.001 \\
\hline TV & -0.1032 & 0.3491 & -0.3 & -0.023 & 0.766 \\
\hline MPHONE & 1.0695 & 0.609 & 1.76 & $0.2593^{*}$ & 0.077 \\
\hline \multirow[t]{3}{*}{ CONSTANT } & -2.4542 & 2.2282 & -1.1 & & \\
\hline & \multicolumn{2}{|c|}{ LR $\chi 2$ (27) } & \multicolumn{3}{|c|}{205.73} \\
\hline & \multicolumn{2}{|c|}{ Prob $>$ chi 2} & \multicolumn{3}{|c|}{0.01} \\
\hline
\end{tabular}

"Significant at $10 \%,{ }^{* *}$ Significant at $5 \%$ and ${ }^{* * *}$ Significant at $1 \%$. Source: Authors' computation using STATA 13. 


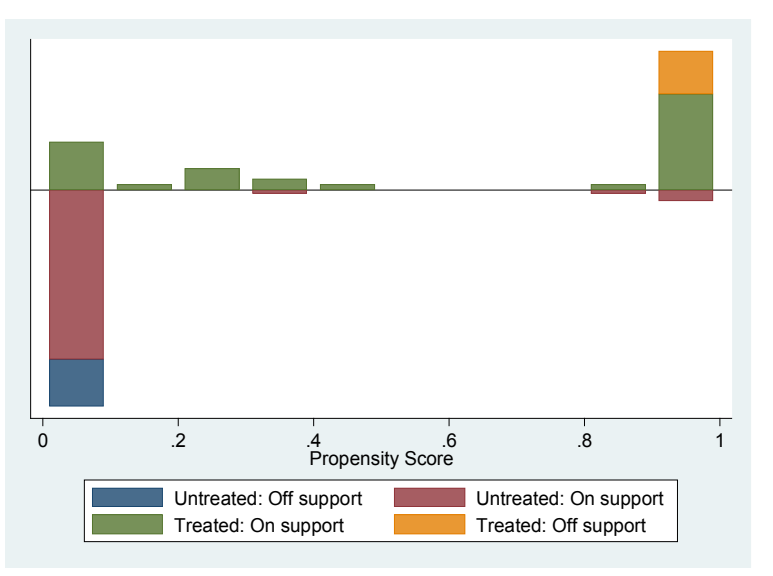

Unmatched

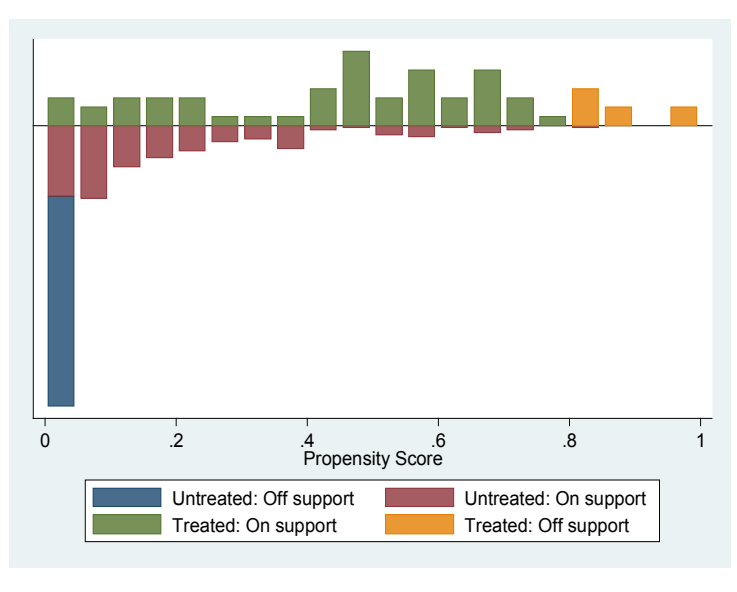

Matched

Participation in Non-farm Employment on Food Security Status of Households

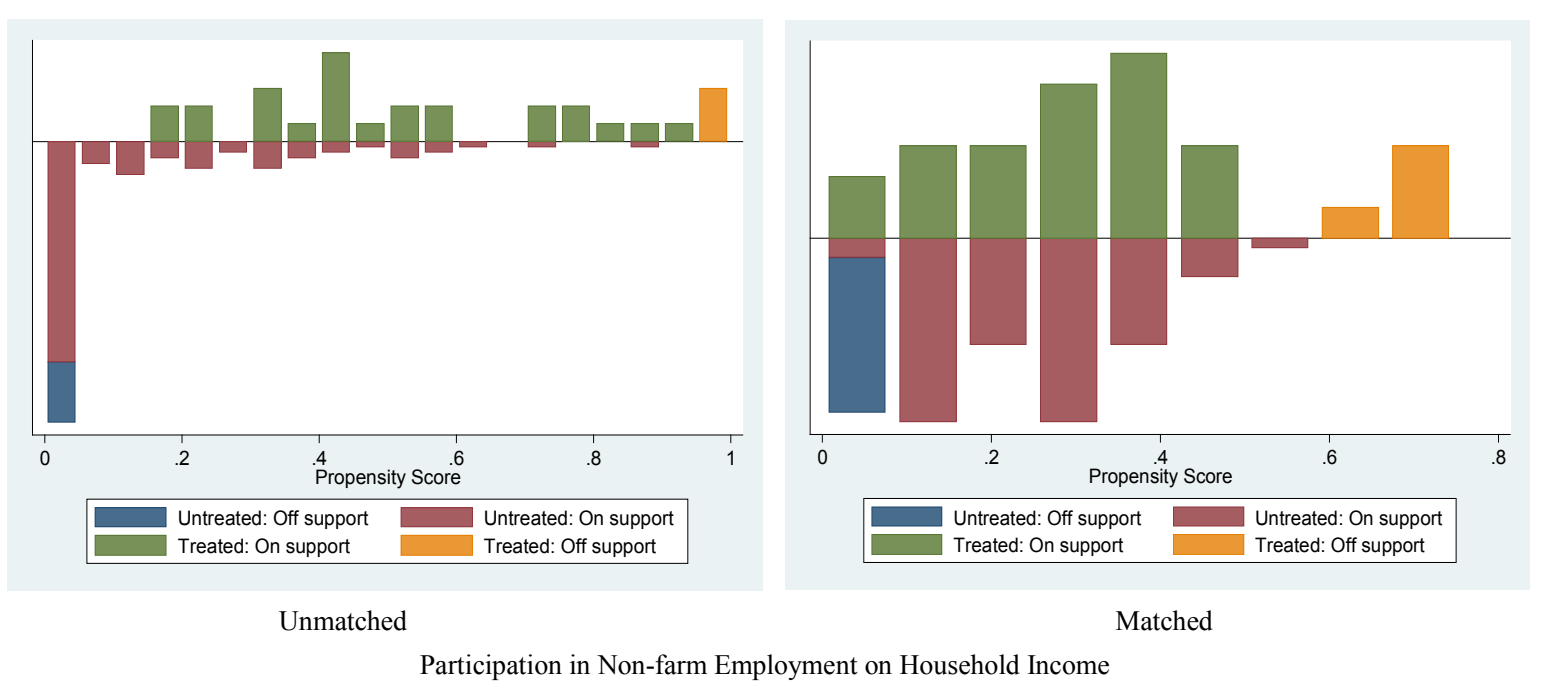

Figure 1. Distribution of propensity scores for unmatched and matched samples. Source: Authors' computation using STATA 13.

Table 7. Treatment effects and sensitivity estimates.

\begin{tabular}{lcccccccc}
\hline \multicolumn{2}{c}{ Outcome Variable } & \multicolumn{2}{c}{ PSM } & \multicolumn{2}{c}{ Critical Value } & \multicolumn{2}{c}{ Treated } & Control \\
\hline \multirow{2}{*}{ Food Security } & \multirow{2}{*}{ ATT } & ATU & ATE & $\Gamma$ & On-support Off-support On-support Off-support \\
& & $0.42^{* * *}$ & $0.33^{* * *}$ & $0.37^{* * *}$ & 3.6 & 173 & 74 & 108 \\
\multirow{2}{*}{ Household Income } & \multirow{2}{*}{ HHINC } & $5527.7^{* * *}$ & $4695.2^{* * *}$ & $5209.6^{* * *}$ & 5.8 & 186 & 61 & 115 \\
& & $(8.39)$ & $(5.71)$ & $(7.96)$ & & & & 38 \\
\hline
\end{tabular}

${ }^{*}$ Significant at $10 \%,{ }^{* *}$ Significant at $5 \%$ and ${ }^{* * *}$ Significant at $1 \%$; Note: t-values in parentheses. Source: Authors' computation using STATA 13.

points. An ATE of 0.37 on food security shows that non-farm work participation increases food security index by 0.37 for the total population. An ATU of 0.32 on food security indicates that if non-participants of non-farm work were to participate, their food security index points would increase by about 0.32 .

The value of the coefficient of the treatment effects indicate that the Average Treatment Effects for the treated (ATT) are higher than the Average Treatment Effects for the whole sample (ATE) and the Average Treatment Effects for the Untreated (ATU) for both household income and food security status. This finding indicates that 
households that have a higher probability of participation in non-farm employment receive higher incomes and enjoy improved food security status compared to households that do not participate in non-farm work. Our findings corroborate [12]. It also confirms the works of [10] and [11] who showed that non-farm work participation boosts household income and welfare.

Results from the sensitivity analysis on hidden bias, which shows the critical levels of gamma $(\Gamma)$ at which the causal inference of participation impact may be questioned are also presented in Table 7. For example, the value of 3.6 implies that if farmers that have the same independent variables differ in their odds of participation by a factor of $60 \%$, the significance of the participation on food security may be questionable. The lowest critical value of $\mathrm{C}=3.6$ and the highest critical value $\mathrm{C}=5.8$ clearly show that very large amounts of unobserved heterogeneity would not distort inference made about the estimated treatment effects. This indicates that the results are generally insensitive to hidden bias.

The indices of matching quality presented in Table 8 show substantial reduction in absolute bias for both outcome variables. Table 8 shows that the mean bias in the independent variables after matching lie under $20 \%$ level of reduction in bias as proposed by [42].

This indicates that the PSM technique significantly balanced the covariates. The pseudo- $\mathrm{R}^{2}$ for both outcome indicators after matching are generally low and all of the diagnostic statistics are significantly equal to zero, showing that the overall outcome from the matching are sufficient in balancing the covariates among non-farm work participants and non-participants [43]. All these findings point to the fact that when farm households in Upper East Region and Upper West Region engage in non-farm work, their food security and incomes are significantly improved.

\section{Conclusions}

This paper sought to investigate the impact of non-farm employment on household income and food security among farm households in the Upper East and Upper West regions of Ghana. A food security index, using the Recommended Daily Calorie Required (RDCR) approach, was constructed to ascertain the food security status of households. We employed the propensity score matching technique to avoid biases arising from unobservable factors that might influence participation in non-farm employment and the outcome variables, namely, household income and food security status.

We found 45 percent of households in the sample to be food insecure. The result suggests that in spite Ghana's remarkable success in halving consumption poverty over the past decades, there exists a relatively high level of food insecurity in the northern Regions as reflected by high poverty incidence indices. The propensity score matching results show that non-farm employment has a statistically significant positive effect on the income of households as well as their food security status. Our findings confirm existing literature on the effects of non-farm activity participation on the welfare of rural farm households. The paper also identifies factors such as basic education attainment, village group membership, road network, distance to the nearest health facility, number of farms owned, and ownership of assets such as motorbike, truck or mobile phone as significant determinants of non-farm work participation.

The results imply that policy must focus on promoting non-farm employment opportunities in rural farming communities in Ghana, especially in the Upper East and Upper West regions, given its impact on food security and incomes. Any policies targeted at promoting food security should go beyond just food production measures; they should include both food production measures and measures that help generate additional incomes for rural farm households through the development of alternative livelihood opportunities. Not only is diversification into

Table 8. Indices of matching quality before and after matching.

\begin{tabular}{|c|c|c|c|c|c|}
\hline Outcome Indicator & $\begin{array}{l}\text { Pseudo-R }^{2} \\
\text { Unmatched }\end{array}$ & $\begin{array}{c}\text { Pseudo-R } \\
\text { Matched }\end{array}$ & $\begin{array}{c}\mu \text { Bias } \\
\text { Unmatched }\end{array}$ & $\begin{array}{c}\mu \text { Bias } \\
\text { Matched }\end{array}$ & $\begin{array}{c}\text { Bias } \\
\text { Reduced }\end{array}$ \\
\hline \multirow[t]{2}{*}{ FS } & 0.223 & 0.063 & 20.7 & 6.9 & 66.67 \\
\hline & $(0.000)$ & $(0.362)$ & & & \\
\hline \multirow[t]{2}{*}{ HHINC } & 0.223 & 0.055 & 20.7 & 6.2 & 70.05 \\
\hline & $(0.000)$ & $(0.444)$ & & & \\
\hline
\end{tabular}

Note: P-Values in parentheses. Source: Authors' computation using STATA 13. 
non-farm work a dependable supplementary source of income for rural households, it also helps in smoothing income and consumption. Thus, while this paper is not advocating for non-farm income activities as a substitute to farming, non-farm work could be a reliable complement to farming activities. Policy should therefore focus on making non-farm work opportunities available to rural households and help them overcome entry barriers. Such measures may include increasing the access of rural households to physical, financial, social and human capital. Physical capital measures such as good roads, dependable electricity supply and general infrastructural development will help to reduce production and transportation costs. Improving access to education in rural communities would also enhance non-farm employment opportunities, particularly, non-farm wage employment. The study shows that membership of a village group has a positive association with non-farm work participation. Promotion of the formation and participation in village groups and associations, including farmer-based organizations, will go a long way in enhancing non-farm employment opportunities for rural farm households.

\section{References}

[1] Economist Intelligence Unit (2015) Global Food Security Index Report. Accessed 30 September 2015. http://foodsecurityindex.eiu.com/Home/DownloadResource?fileName=EIU\%20Global\%20Food\%20Security $\% 20$ Inde x\%20-\%202015\%20Findings $\% 20 \% 26 \% 20$ Methodology.pdf

[2] Davis, J.R. (2004) The Rural Non-Farm Economy, Livelihoods and their Diversification: Issues and Options'. Natural Resource Institute Report No: 2753, Chatham, UK, Accessed 26 August 2015. http://econwpa.repec.org/eps/dev/papers/0510/0510016.pdf

[3] Gladwin, C.H., Thomson, A.M., Paterson, J.S. and Anderson, A.S. (2001) Addressing Food Security in Africa via Multiple Livelihood Strategies of Women Farmers'. Food Policy, 26, 177-207. http://dx.doi.org/10.1016/S0306-9192(00)00045-2

[4] Diao, X., Hazell, P., Resnick, D. and Thurlow, J. (2007) The Role of Agriculture in Development: Implications for Sub-Saharan Africa'. Research Report 153, International Food Policy Research Institute, Washington DC.

[5] Barrett, C.B. and Reardon, T. (2000) Asset, Activity and Income Diversification among African Agriculturalists, Some Practical Issues. Project Report to USAID BASIS CRSP, Accessed 30 January 2008. http://barrett.dyson.cornell.edu/Papers/BASIS1.pdf

[6] Reardon, T., Crawford, E. and Kelly, V. (1994) Links between Nonfarm Income and Farm Investment in African Households: Adding the Capital Market Perspective. American Journal of Agricultural Economics, 76, 1172-1176. http://dx.doi.org/10.2307/1243412

[7] Barrett, C.B., Reardon, T. and Webb, P. (2001) Nonfarm Income Diversification and Household Livelihood Strategies in Rural Africa: Concepts, Dynamics and Policy Implications. Food Policy, 26, 315-331. http://dx.doi.org/10.1016/S0306-9192(01)00014-8

[8] Ellis, F. (1998) Survey Article: Household Strategies and Rural Livelihood Diversification. Journal of Development Studies, 35, 1-38. http://dx.doi.org/10.1080/00220389808422553

[9] Food and Agricultural Organization (2013) The State of Food Insecurity in the World. The Multiple Dimensions of Food Security. Food and Agriculture Organization of the United Nations, Rome.

[10] Katera, L. (2013) Off-Farm Incomes: A Haven for Women and Youth in Rural Tanzania? A Paper Presented at REPOA's 18th Annual Research Workshop Held at the Kunduchi Beach Hotel, Dar es Salaam, 3-4 April 2013, 1-26.

[11] Owusu, V., Abdulai, A. and Abdul-Rahaman, S. (2011) Non-Farm Work and Food Security among Farm Households in Northern Ghana. Food Policy, 36, 108-118. http://dx.doi.org/10.1016/j.foodpol.2010.09.002

[12] Babatunde, R.O. and Qaim, M. (2010) Impact of Off-Farm Income on Food Security and Nutrition in Nigeria. Food Policy, 35, 303-311. http://dx.doi.org/10.1016/j.foodpol.2010.01.006

[13] Norton, A., Bortei-Doku Aryeetey, E., Korboe, D. and Dogbe, D.K.T. (1995) Poverty Assessments in Ghana. Using Qualitative and Participatory Research Methods. PSP Discussion Paper Series No. 83, The World Bank.

[14] Quaye, W. (2008) Food Security Situation in Northern Ghana, Coping Strategies and Related Constraints. African Journal of Agriculture Research, 3, 334-342.

[15] Regassa, N. (2011) Small Holder Farmers Coping Strategies to Household Food Insecurity and Hunger in Southern Ethiopia. Ethiopian Journal of Environmental Studies and Management, 4, 39-48.

[16] Ayoade, A.R. and Adetunbi, S.I. (2013) Determination of Farmers' Coping Strategies to Household Food Insecurity in Oyo State, Nigeria. American Journal of Social and Management Science, 4, 1-7.

[17] Reardon, T., Delgado, C. and Matlon, P. (1992) Determinants and Effects of Income Diversification amongst Farm Households in Burkina Faso. The Journal of Development Studies, 28, 264-296. 
http://dx.doi.org/10.1080/00220389208422232

[18] Alderman, H. and Paxson, C.H. (1992) Do the Poor Insure? A Synthesis of the Literature on Risk and Consumption in Developing Countries. Policy Research Working Papers, WPS 1008, the World Bank.

[19] Dercon, S. (2002) Income Risk, Coping Strategies, and Safety Nets. World Bank Research Observer, 17, 141-166. http://dx.doi.org/10.1093/wbro/17.2.141

[20] Lay, J. and Schuler, D. (2008) Income Diversification and Poverty in a Growing Agricultural Economy: The Case of Ghana. Proceedings of the German Development Economics Conference, Zurich, 2008, No. 39, 1-39.

[21] Fox, L. (2015) Are African Households Heterogeneous Agents? Stylized Facts on Patterns of Consumption, Employment, Income and Earnings for Macroeconomic Modelers. IMF Working Paper No. 102, Research Department, and Strategy, Policy, and Review Department.

[22] Ministry of Food and Agriculture (2010) Northern Ghana Food Security and Nutrition Monitoring System. Accra.

[23] Owusu, V. and Abdulai, A. (2009) Nonfarm Employment and Poverty Reduction in Rural Ghana: A Propensity-Score Matching Analysis. Contributed Paper Prepared for Presentation at the International Association of Economists Conference, Beijing, 16-22 August 2009, 1-16.

[24] Senadza, B. (2011) Non-Farm Income Diversification in Rural Ghana: Determinants and Implications for Income Distribution and Welfare. VDM: Verlag Dr. Mueller, Saarbrucken.

[25] Godden, B. (2004) Sample Size Formulas. http://williamgodden.com/samplesizeformula.pdf

[26] Ghana Statistical Service (2012) 2010 Population and Housing Census: Summary Report of Final Results. Accra.

[27] Ghana Statistical Service (2014) Poverty Profile in Ghana: 2005-2013. Accra.

[28] Babatunde, R.O., Omotosho, O.A. and Sholotan, O.S. (2007) Factors Influencing Food Security Status of Rural Farming Households in North Central Nigeria. Agricultural Journal, 2, 351-357.

[29] Kuwornu, J.K.M., Demi, S.M. and Amegashie, D.P.K. (2013) Analysis of Food Security Status of Farming Households in the Forest Belt of the Central Region of Ghana. Russian Journal of Agricultural and Socio-Economic Sciences, 1, 26-42. http://dx.doi.org/10.18551/rjoas.2013-01.04

[30] Ghana Statistical Service (2008) Ghana Living Standards Survey, Report of the Fifth Round (GLSS 5). Accra.

[31] International Food Policy Research Institute, IFPRI (1999) Choosing Outcome Indicators of Household Food Security. Technical Guide 7, Washington DC.

[32] Grosvenor, M.B. and Smolin, L.A. (2005) Nutrition: Everyday Choices. Wiley, Hoboken.

[33] Huffman, W.E. (1991) Multiple Job-Holding among Farm Families. In: Findeis, J.L., Hallberg, M.C. and Lass, D.L., Eds., Agricultural Households Survey and Critique, Iowa State University Press, Ames, 79-111.

[34] Escobal, J. (2001) The Determinants of Nonfarm Income Diversification in Rural Peru. World Development, 29, 497508. http://dx.doi.org/10.1016/S0305-750X(00)00104-2

[35] Canagarajah, S., Newman, C. and Bhattamishra, R. (2001) Non-Farm Income, Gender, and Inequality: Evidence from rural Ghana and Uganda. Food Policy, 26, 405-420. http://dx.doi.org/10.1016/S0306-9192(01)00011-2

[36] Abdulai, A. and CroleRees, A. (2001) Determinants of Income Diversification amongst Rural Households in Southern Mali. Food Policy, 26, 437-452. http://dx.doi.org/10.1016/S0306-9192(01)00013-6

[37] Newman, C. and Canagarajah, S. (2000) Gender, Poverty and Nonfarm Employment in Ghana and Uganda. Policy Research Working Paper Series 2367, the World Bank.

[38] Shahidur, R., Chilot, Y., Befekadu, B. and Solomon, L. (2010) Pules Value Chain in Ethiopia; Constraints and Opportunities for Enhancing Exports. International Food Policy Research Institute.

[39] Dehejia, R.H. and Wahba, S. (1999) Causal Effects in Non-Experimental Studies: Re-Evaluating the Evaluation of Training Programmes. Journal of the American Statistical Association, 94, 1053-1062. http://dx.doi.org/10.1080/01621459.1999.10473858

[40] Becker, S.O. and Ichino, A. (2002) Estimation of Average Treatment Effects Based on Propensity Scores. The Stata Journal, 2, 358-377.

[41] Faltermeier, L. and Abdulai, A. (2009) The Adoption of Water Intensification Technologies and Farm Income: A Propensity Score Analysis for Rice Farmers in Northern Ghana. Agricultural Economics, 40, 365-379. http://dx.doi.org/10.1111/j.1574-0862.2009.00383.x

[42] Rosenbaum, P.R. and Rubin, D. (1985) Constructing a Control Group Using Multivariate Matched Sampling Methods that Incorporate the Propensity Score. The American Statistician, 39, 33-38.

[43] Becerril, J. and Abdulai, A. (2009) The Impact of Improved Maize Varieties on Poverty in Mexico: A Propensity Score Marching Approach. World Development, 38, 1024-1035. http://dx.doi.org/10.1016/j.worlddev.2009.11.017 